\title{
Review of prostate cancer research in Nigeria
}

\author{
Titilola O Akinremi $^{1 *}$, Chidiebere N Ogo ${ }^{2}$, Ayodeji O Olutunde ${ }^{1}$ \\ From The Science of Global Prostate Cancer Disparities in Black Men \\ Jacksonville, FL, USA. 27-29 August 2010
}

\begin{abstract}
Prostate cancer (CaP) disparities in the black man calls for concerted research efforts. This review explores the trend and focus of $\mathrm{CaP}$ research activities in Nigeria, one of the ancestral nations for black men. It seeks to locate the place of the Nigerian research environment in the global progress on CaP disparities. Literature was reviewed mainly through a Pubmed search with the terms "prostate cancer"and "Nigeria", as well as from internet and hard copies of journal pages.

Findings: One of the earliest publications about CaP in Nigeria was in 1973 from the nation's 1st tertiary hospital in Ibadan, reporting low incidence, followed by a lull of nearly one decade. In 1980, the incidence rate of CaP was reported as almost similar for black men in Ibadan and Washington and from then on, research work from surgeons and pathologists, from the south to the north, east to west, continued to report increasing prevalence of CaP. Apart from epidemiology, other areas of research include KAP (knowledge attitude and practice) studies (poor education of caregivers and population), histopathology (mostly adenocarcinoma), diagnosis (digital rectal examination [DRE], prostate specific antigen [PSA], ultrasound), clinical features (late presentation and high mortality), and prevention (lifestyle, education and screening). As of today there is a gaping dearth of molecular and genetic studies. Conclusion: The global focus on CaP disparities in black men calls for more efforts from Africa, in all areas of research, along with international collaborations for capacity building.
\end{abstract}

\section{Background}

Prostate Cancer has become the number one cancer in men with increasing incidence and morbidity in men of black African ancestry $\left[{ }^{1}\right]$. Its incidence and prevalence in black men is in multiples of those from other races in several studies $\left[{ }^{2}\right]$. The reason for this is not yet clear cut and an explanation for the disparity may lie in studies involving black men from different populations to see if there is an enhancing factor associated with the racial origins of these men. Nigeria is an ancestral home of many black men living outside Africa and it is hoped that an exploration of research activities emanating from the country may shed some light on the disparity [3]. Odedina et al [4] recommend the need to focus on areas of genetic and environmental risk factors in the group.

\footnotetext{
* Correspondence: bakinremi2@aol.com

${ }^{1}$ Department of Pathology, Federal Medical Centre, Abeokuta, Nigeria

Full list of author information is available at the end of the article
}

\section{Methods}

Research studies emanating from Nigeria or involving Nigerian subjects in relation to $\mathrm{CaP}$ were sourced using the U.S. National Library of Medicine literature search engine, PubMed [5], using the search terms "prostate cancer" and "Nigeria". Other sources included journal websites and hard copies of journal articles. These gave reports on $\mathrm{CaP}$ from all regions of the country, covering topics including epidemiology, clinical presentation, diagnosis, treatment and prevention.

\section{Findings \\ Epidemiology}

In 1973, Nkposong and Lawani[6], urologists from the University College Hospital, Ibadan, South West Nigeria, at the time the only referral center for cancer treatment, noted a low but increasing incidence of prostate cancer. It moved from $8^{\text {th }}$ position of male cancers in 1969 to $2^{\text {nd }}$ place by 1979 , with liver cancer leading the pack [7]. In 1981, Udeh [8] also reported the same position from Enugu, but up till 2002, Globocan [9] reported that CaP 
was not among the top 5 cancers in developing countries.

Angwafo [10], while reporting $93.8 / 10^{5}$ incidence from Cameroon in 1994, asked the question "Is prostate cancer rare in black Africa?" while Osegbe [11] in a report from Lagos where the hospital incidence was put at $127 / 10^{5}$, surmised that incidence of CaP may be underestimated in Nigerians. Similar reports of increasing hospital based incidence came from other parts of Nigeria with rates of $61.3 / 10^{5}$ from Calabar [12] and $182.5 / 10^{5}$ from Ife [13]. The stance of Globocan has since changed with the 2008[14] report that $\mathrm{CaP}$ had become the top male cancer and fourth commonest cancer in Nigeria.

Ogunbiyi and Shittu [15] from the Ibadan Cancer Registry in 1999 announced a definite increase of CaP among Nigerians. It had risen from $8^{\text {th }}$ position in 1969 to $1^{\text {st }}$ position in 1996 , being $11 \%$ of all male cancers. Studies from Kano [16], Zaria [17], Benin [18] and Maiduguri [19] showed $\mathrm{CaP}$ as16.5\%, 9.2\%, 7.13\% and 6.15\% of male cancers.

\section{Clinical presentation}

Reports from all regions of the country emphasize late presentation as the pattern in Nigerian CaP patients. From both South [12] and North [19] about two thirds of patients presented with metastatic disease, and $94.2 \%$ [13] and 91\% [20] presented with complications respectively. Mortality was generally high with $64 \%$ dead within 2 years in a review by Osegbe [11]. Metastases were typically to the spine, with attendant paraparesis or paraplegia, and rare orbital metastases were reported from Ibadan [21].

\section{Diagnosis}

There is growing concern that medical students are not gaining enough skills in DRE [22], such that clinical diagnosis of CaP may become a dilemma for the younger generation of doctors. Though final year students at the University of Jos have adequate teaching, right attitude, perspective, and knowledge about examining for prostate cancer, they have not translated the same into practice and $86 \%$ had never felt a malignant prostate while $45 \%$ had never examined the gland [23].

Iko [24] in 1987 suggested that prostatic ultrasonography may have great diagnostic promise in developing economies where more sophisticated equipments may be uncommon. However, Ajape [25] in a more recent report(2010) noted 50\% sensitivity and false negative correlation between ultrasound and $\mathrm{CaP}$ diagnosis.

\section{Histopathology}

Studies from all regions of the country found that adenocarcinoma is the predominant histologic type, similar to global findings. $\mathrm{CaP}$ constitutes a moderate portion of biopsies of the prostate. Studies from Benin [18], Ilorin [26] , and Kano [16] also reported malignancy rates of $17 \%, 16.9 \%$ and $22.4 \%$ respectively. Freeman et al [27] compared the Gleason system interpretation between genitourinary pathologists in Nigeria, Jamaica and US and concluded that the revealed concordance makes international studies using this grading system feasible.

\section{PSA}

Although (PSA) is a controversial instrument for screening, it remains a useful parameter for monitoring treatment. The distribution of PSA in a rural Nigerian population was found to be similar to that of unscreened US populations with greater than $4 \mathrm{ug} / \mathrm{l}$ readings in $14 \%$ of men [28], and Igwe [29] found that $85.1 \%$ prostate cancer patients had total PSA above the normal cut off level. The median total PSA in $\mathrm{CaP}$ was found to be 92.6ug/l and 106ug/l respectively in Ibadan [30] and Ife [12].

\section{Prevention}

There is not yet any national cancer screening program and annual PSA checks are not practiced routinely in Nigeria. Lifestyle and behavioral patterns are known to be important in cancer prevention but education about $\mathrm{CaP}$ is sparse in Nigeria and opportunistic. Ajape et al [31] concluded that "there is remarkable lack of awareness of prostate cancer among the Nigerian urban populace. Prostate cancer screening and serum PSA test for screening is globally unknown among them". Though knowledge and risk perception of prostate cancer were low, Oladimeji et al [32] found that $81.5 \%$ were willing to be screened for the disease. Odedina et al [33] suggested that emigration of Nigerian men from Nigeria to the US has a significant impact on prostate cancer knowledge and beliefs. Comparing indigenous and immigrant Nigerian men's diet, alcohol consumption, tobacco use and physical activities, Kumar et al [34] found that there were enough differences to provoke deeper search. Meanwhile, reporting from Nsukka , Ejike and Ezeanyiwa [35] suggested that lifestyle changes in Nigerian men leading to westernized diet and use of energy sparing devices (status symbols) may lead to increase in incidence of chronic diseases like cancer. A trend towards high total plasma omega- 6 was observed and found to have a moderate positive correlation with prostate cancer in Nigerians [36].

\section{Treatment}

Since most patients present with poor prognostic features including high histological grades and clinical stages, treatment is mostly palliative with bilateral orchidectomy with or without anti androgen therapy [37]. 
A discomforting finding in Ilorin showed that only $38.9 \%$ of patients had histopathological diagnosis before treatment[25]. No clinical trials were reported.

\section{Conclusion}

Prostate cancer research in Nigeria is growing and multifaceted. There is a need to collate figures into the National Cancer Registry. Education and knowledge about prostate cancer is sparse, and even medical students need better training in digital rectal examination. Patients often present late with complications, pathological diagnosis is mostly of adenocarcinona, resulting commonly in palliative orchiectomy. Routine screening is not practiced and most PSA testing and digital rectal examination emanate from surgical clinics. The disparity in prostate cancer prevalence and mortality in the black man calls for concerted efforts from all and sundry to include all areas of research. Nigerian researchers stand at a vantage position to carry out local work as well as collaborate with other stakeholders all over the world.

\section{Acknowledgements}

This article has been published as part of Infectious Agents and Cancer Volume 6 Supplement 2, 2011: Proceedings of the First Biennial Conference on the Science of Global Prostate Cancer Disparities in Black Men. The full contents of the supplement are available online at http://www. infectagentscancer.com/supplements/6/S2.

\section{Author details}

${ }^{1}$ Department of Pathology, Federal Medical Centre, Abeokuta, Nigeria.

${ }^{2}$ Department of Urology, Federal Medical Centre, Abeokuta, Nigeria.

\section{Competing interests}

The authors declare that they have no competing interests.

Published: 23 September 2011

\section{References}

1. Delongchamps NB, Singh A, Haas GP: Epidemiology of prostate cancer in Africa: another step in the understanding of the disease? Curr Probl Cancer 2007, 31(3):226-36.

2. Odedina FT, Ogunbiyi JO, Ukoli FA: Roots of prostate cancer in AfricanAmerican men. J Natl Med Assoc 2006, 98(4):539-43.

3. Onuigbo Wl: Carcinoma of the prostate: indigenous patterns. J Natl Med Assoc 1984, 76(4):373-5.

4. Odedina FT, Akinremi TO, Chinegwundoh F, Roberts R, Yu D, Reams RR, Freedman ML, Rivers B, Green BL, Kumar N: Prostate cancer disparities in Black men of African descent: a comparative literature review of prostate cancer burden among Black men in the United States, Caribbean, United Kingdom, and West Africa. Infect Agent Cancer 2009, 10(4 Suppl 1):S2.

5. PUBMED. [http://www.ncbi.nlm.nih.gov/pubmed].

6. Nkposong EO, Lawani J: Primary carcinoma of the prostate in Ibadan. West Afr Med J Niger Med Dent Pract 1973, 22(6):108-11.

7. Abioye AA: The Ibadan Cancer Registry. In Cancer in Africa, Proceedings of a Workshop of the West African College of Physicians. Ibadan Nigeria: The Caxton Press (West Africa) Limited;Olatubosun DA 1981:1-33.

8. Udeh FN: Prostatic carcinoma in Nigeria: a 10-year retrospective study. Int Urol Nephrol 1981, 13(2):159-66.

9. Parkin DM, Bray F, Ferlay J, Pisani P: Estimating the world cancer burden. Int J Cancer 2001, 15(94(2)):153-6, Globocan 2000.

10. Angwafo FF: Migration and Prostate Cancer: An International Perspective. J Natl Med Assoc 1998, 90(11 Suppl):S720-S723.
11. Osegbe DN: Prostate cancer in Nigerians: facts and nonfacts. J Urol 1997, 157(4):1340-1343.

12. Ekwere PD, Egbe SN: The changing pattern of prostate cancer in Nigerians: current status in the southeastern states. J Natl Med Assoc 2002, 94(7):619-27.

13. Badmus TA, Adesunkanmi AR, Yusuf BM, Oseni GO, Eziyi AK, Bakare TI, Adetiloye JA, Badmus SA: Burden of prostate cancer in southwestern Nigeria. Urology 2010, 76(2):412-6, Epub 2010 May 7.

14. Ferlay J, Shin HR, Bray F, Forman D, Mathers C, Parkin DM: GLOBOCAN 2008, Cancer Incidence and Mortality Worldwide. IARC Cancer Base No. 10 [Internet] Lyon, France: International Agency for Research on Cancer; 2010, Available from: http://globocan.iarc.fr.

15. Ogunbiyi JO, Shittu OB: Increased incidence of prostate cancer in Nigerians. J Natl Med Assoc 1999, 91(3):159-64.

16. Mohammed AZ, Alhassan SU, Edino ST, Ochicha O: Histopathological review of prostatic diseases in Kano, Nigeria. Niger Postgrad Med J 2003, 10(1):1-5.

17. Afolayan EA: Five years of Cancer Registration at Zaria. Niger Postgrad Med J 2004, 11(3):225-9.

18. Akang EE, Aligbe JU, Olisa EG: Prostatic tumours in Benin City, Nigeria. West Afr J Med 1996, 15(1):56-60.

19. Dawam D, Rafindadi AH, Kalayi GD: Benign prostatic hyperplasia and prostate carcinoma in native Africans. BJU Int 2000, 85(9):1074-7.

20. Yawe KT, Tahir MB, Nggada HA: Prostate cancer in Maiduguri. West Afr $J$ Med 2006, 25(4):298-300.

21. Shittu $O B$, Ogunbiyi JO: Orbital metastases of prostatic carcinoma in a tropical African population. West Afr J.Med 2003, 22(2):173-6.

22. Eziyi AK, Ademuyiwa AO, Eziyi JAE, Salako AA: Digital Rectal Examination for prostate and rectal tumour: Knowledge and experience of Medical students. W. Afr. Med. J 2009, 28(5):318-322

23. Dakum K, Ramyil VM, Agbo S, Ogwuche E, Makama BS, Kidmas AT: Digital rectal examination for prostate cancer: attitude and experience of final year medical students. Niger J Clin Pract 2007, 10(1):5-9.

24. Iko BO, Monu JU, Mangete ED, Nduka NR: Ultrasonography of the prostate: a preliminary report from Nigeria. Int Urol Nephrol 1987, 19(3):279-85.

25. Ajape AA, Ibrahim KO, Fakeye JA, Abiola OO: An overview of cancer of the prostate diagnosis and management in Nigeria: The experience in a Nigerian tertiary hospital. Ann. Afr. Med 2010, 9(3):113-117.

26. Anjorin AS, Adeniji KA, Ogunsulire IA: Histopathological study of prostate cancer in Ilorin, Nigeria. Central Afr J Med 1998, 44(3):72-75.

27. Freeman VL, Coard KC, Wojcik E, Durazo-Arvizu R: Use of the Gleason system in international comparisons of prostatic adenocarcinomas in blacks. Prostate 2004, 58(2):169-73.

28. Ukoli F, Osime U, Akereyeni F, Okunzuwa O, Kittles R, Adams-Campbell L: Prevalence of elevated serum prostate-specific antigen in rural Nigeria. Int J Urol 2003, 10(6):315-22.

29. Igwe CU, Ikaraoha Cl, Ogunlewe JO, Nwobu GO, Duru LAD, Mokogwu ATH: The Study Of Serum Prostate Specific Antigen And Phosphatase Isoenzymes Activity As Diagnostic Parameters In Patients With Prostate Cancer In Nigeria. Online J Health Allied Scs 2004, 3:3 [http://www.ojhas. org/issue11/2004-3-3.htm].

30. Abbiyesuku FM, Shittu OB, Oduwole OO, Osotimehin BO: Prostate specific antigen in the Nigerian African. Afr J Med Med Sci 2000, 29(2):97-100.

31. Ajape AA, Babata A, Abiola OO: Knowledge of prostate cancer screening among native African urban population in Nigeria. Nig Q J Hosp Med 2009, 19(3):145-7.

32. Oladimeji O, Bidemi YO, Olufisayo JA, Sola AO: Prostate Cancer Awareness, Knowledge, and Screening Practices among Older Men in Oyo State, Nigeria. Int Q Community Health Educ 2009-2010, 30(3):271-86.

33. Odedina FT, Yu D, Akinremi TO, Reams RR, Freedman ML, Kumar N: Prostate cancer cognitive-behavioral factors in a West African population. J Immigr Minor Health 2009, 11(4):258-67, Epub 2008 Dec 4.

34. Kumar NB, Yu D, Akinremi TO, Odedina FT: Comparing dietary and other lifestyle factors among immigrant Nigerian men living in the US and indigenous men from Nigeria: potential implications for prostate cancer risk reduction. J Immigr Minor Health 2009, 11(5):391-9, Epub 2009 Feb 19.

35. Ejike CE, Ezeanyika LU: Lifestyle changes in Nsukka Metropolis in relation to prostate cancer and benign prostate hyperplasia. Niger. J. Biochem Mol. Biol 2009, 24(1):54-48. 
36. Ukoli FA, Akumabor PN, Oguike TC, Dent LL, Beech D, Osime U: The association of plasma fatty acids with prostate cancer risk in Nigerians. Ethn Dis 2009, 19(4):454-61.

37. Olapade-Olaopa EO, Obamuyide HA, Yisa GT: Management of advanced prostate cancer in Africa. Can J Urol 2008, 15(1):3890-8.

doi:10.1186/1750-9378-6-S2-S8

Cite this article as: Akinremi et al:: Review of prostate cancer research in Nigeria. Infectious Agents and Cancer 2011 6(Suppl 2):S8.

Submit your next manuscript to BioMed Central and take full advantage of:

- Convenient online submission

- Thorough peer review

- No space constraints or color figure charges

- Immediate publication on acceptance

- Inclusion in PubMed, CAS, Scopus and Google Scholar

- Research which is freely available for redistribution

Submit your manuscript at www.biomedcentral.com/submit
Ciomed Central 